\title{
Improving Students' Achievement in Writing Descriptive Paragraph through Teaching Prewriting Stages
}

\section{Puji Hariati}

Amik Medicom, Indonesia

Pujinasution512@gmail.com

\begin{abstract}
This study was aimed to find out whether or not Teaching Prewriting Stages can improve students' ability in writing descriptive paragraphs, to describe the role of prewriting stages in helping the students to write descriptive paragraphs. This study was conducted by using Classroom Action Research. It was done through 1) planning, 2) action, 3) observation, and 4) reflection. The population and the sample was the ninth grade students of SMP Swasta BUDISATRYA at 2018/2019 academic year. This research applied quantitative and qualitative method. Quantitative data were taken from the students' writing descriptive paragraph test. Qualitative data were taken from observation, interview, and diary notes. The result of the research shows that there was some improvement of students' ability in writing descriptive paragraphs through teaching prewriting stages. It can be proved from the students' score which improved from cycle 1 to cycle 2. The improvement can be seen that in pre test the means score was 33.52. In the first cycle, meeting 1 the means score was 37.35, in meeting 2 was 42.64 and in meeting 3 was 52.64. In the second cycle, meeting 1 the means score was 64,41, in meeting 2 was 80 and in meeting 3 was 91.17. The improvement also can be seen from the percentage of the students' achievement in writing descriptive paragraph by using prewriting stage; in pre test, no one of the students got 75 points. In the first cycle, in meeting 1 , and meeting 2 , there was also no one student got 75 point, but in meeting 3 there was 23,52\% (8 students) got 75 points. It means there was an improvement about $23.52 \%$. In the second cycle, in meeting 1 there was $29.41 \%$ (10 students) got 75 points, it means that there was an improvement about $5.89 \%$. In meeting 2 there was $79.41 \%$ (27 students) got 75 points, it means that there was an improvement about 50\%. In meeting 3 there was $100 \%$ (34 students) got up 75 points. It means that prewriting stages helped the students to write descriptive paragraphs through brainstorming, listing supporting point, making a simple outline to write event, place or object related to the topic. So, the students' achievement in writing descriptive paragraph is significantly improved by applying prewriting stage.
\end{abstract}

Keywords

Achievement; witing, descriptive paragraph; teaching

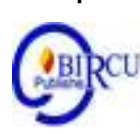

\section{Introduction}

In learning English, the learners have to be able to achieve the four language skills, such as listening, speaking, reading and writing. Since it is generally learned from the secondary level of education and beyond, it implies that after the language for six years, it is expected that learners will be able to use it at least in simple, oral and written 
communication as the basic language that can be used for their further studies. But reality shows that students who have learned it for six years are not as successful the government have expected them to be especially in writing skills.

Writing is part of the skills which exposes facts and ideas by presenting, explaining or interpreting them in some clear, effective and organized way. Writing began at the time when man learned how to communicate his thoughts and feeling by means of visible signs, understandable not only to himself but also to all other persons. It is really a system of human intercommunication.

Some high school teachers think that writing has always been the toughest job, because of the torture of marking the students' work, and because of the relationship to the teaching of other skills such as listening, speaking, writing and reading for which Allen and Vallette (1981: 5) commented that writing may be considered the most difficult of the language skills. It means that most of the students still find difficult to write. They can not know how to write their ideas or opinion in their writing, especially in writing descriptive paragraph.

Prewriting stage is used as educational media especially intended to improve writing skills. Teachers of English often express their concern about the inability of the Junior High School students to write event short description of what they observe in their everyday life. This evidence is also supported by the researcher's experience when she had her Teaching Practice. When she asked her ninth grade students to write descriptive paragraph, their writing product are read like literal translation from Indonesia into English and they always made misspelling words and omissions. The interference of their native language was sometimes so great that she had to ask them what they intended to say. Other problems that most students encountered were the difficulties in generating ideas and determining the choice of tense.

Many explanation are put up to find out two causes of the weakness. Some criticized that the students were weak in writing practice, so they should be given a great amount of writing practice. Other teachers admitted that they had no experience in teaching the subject for themselves who have seldom written their life experience. In fact, there is no defining solution to the whole questions of how the students find the subject difficult unless the teachers try to find out the problems and solve them.

\subsection{The Identification of the Problem}

The problems of the study are identified as follows

1. The improvement of students' ability in writing descriptive paragraphs through teaching prewriting stages.

2. The role of prewriting stages to help the students to write descriptive paragraphs.

\subsection{Scope and Limitation}

The researcher limited her study on the improvement of students' writing descriptive paragraphs through teaching prewriting stages. The subjects of the study were the third year students of SMP BUDISATRYA of 2018/219 academic year.

\subsection{The Formulation of the Problem}

The problems in this study were formulated as follows:

1. Is there any improvement of students' ability in writing descriptive paragraphs through teaching prewriting stages?

2. To what extent prewriting stages helped the students to write descriptive paragraphs? 


\subsection{The Objective of the Study}

The objectives of study are:

1. To find out the improvement of students' ability in writing descriptive paragraphs through teaching prewriting stages.

2. To describe the role of prewriting stages in helping the students to write descriptive paragraphs.

\subsection{The Significance of the Study}

The result of this study is expected to be useful for the improvement of student's achievement in writing descriptive paragraph through prewriting stage. The findings of the study will help teachers improve their strategies in teaching writing by using prewriting stage. With these in mind, the out come of this study will be useful in minimizing the difficulties of the students in writing and giving more motivations to students in writing descriptive paragraph in achieving students in learning English.

\section{Review of Literatures}

\subsection{Writing}

Amato and Snow (2005:34) state that one of the best ways to help students grasp the complex language and structure of textbook is through writing. Writing increases students' understanding of text structure because it causes them to think like writers. Writing helps students to think about text ideas carefully and analytically.

In delivering ideas, a writer must produce a piece of writing which embodies correctness of form, appropriateness of style and unity of theme. It means that writing is one of language skills which expose facts, stories, or ideas by presenting and explaining them in a clear, objective and organized way in the written form. Sipayung (2018) state that understanding a written text means extracting the required information from it as efficiently as possible.

There are five important qualities of good writing. They are:

a) Writing should have focus

An essay should have a single clear central idea. Each paragraph should have a clear main point or topic sentence.

b) Writing should have development

Each paragraph should support tile central idea of the paper. Individual sentences should support the main point of the paragraph.

c) Writing should have unity

Every paragraph in an essay should be related to the main idea. Each paragraph should stick to its main point.

d) Writing should have coherence

An essay or paper should be organized logically, flow smoothly, and "stick" together. In other words, everything in tile writing should make sense to a reader.

e) Writing should have correctness

A paper should be written in generally correct Standard English, with complete sentences, and be relatively error-free. 


\subsection{Writing Descriptive}

Gerot and Wignell (1994:46) : "Description is a writing that describing the thing, people, place or the situation". Then, Mc Crimmon (1984: 158) says, "Description refers to the process of describing something with a skill in words so that the readers may find a clear impression to certain objects".

From the two explanations, it can be concluded that description is a writing that always present a person, place or thing. It can be used as a technique to enrich other forms of writing or as a domain strategy for developing a picture of what something looks like. It attempts to evoke all the sense by identifying a subject's significant features and by arranging those features in an appropriate pattern. When describing something, it needs to capture details. Specific vivid details must be selected so that the readers can see what the author sees. Details must be presented according to a pattern that helps the readers understand why one subject is interesting and significant.

\subsection{Prewriting Stage}

Bazerman (1985: 438) says that the more people have prepared themselves in the prewriting period, the more exciting the writing becomes. This good beginning is very important and it can make the writer success in his writing, like Gere (1985:27) states that to make writing without preparing often makes deeply stress because hardest stage in writing is starting. White (1986: 18) gives two kinds of activities that can be done in writing stage, namely brainstorming, and free writing. It will be given a brief explanation about each of the activities as below:

- Brainstorming can be done individually or group. Before doing Brainstorming, students must be given a writing topic. Then students start to write things that have relation to the topic as much as possible in words or phrase.

- Free writing is done individually. In doing free writing, students asked to write without stopping for several times (5-15 minutes). The students may write whatever that gets in their mind.

\subsection{An Analysis of Prewriting Stage in Writing Descriptive Paragraph}

It is describes before, students will be asked to write descriptive paragraph, before they practice how to write in five or ten minutes. The main role for prewriting in writing might be known by the teachers who will apply prewriting in their teaching, that is prewriting can motivate the students and make them want to pay attention and take part. Moreover, according to Oshima and Hogue (1988), before you can write a well-organized paragraph with good supporting sentence, you need to do some prewriting activities. The following are the prewriting activities.

\section{a. Step 1: Brainstorming}

Brainstorming is a prewriting activity in which you write down any ideas or feelings you have about the subject of your topic sentence. Do it this way:

a. Write down your topic sentence.

b. Make a list of everything that comes to your mind about the subject. (Do not worry about the controlling idea for now.)

c. Forget about order of ideas, grammar, structure, or spelling. (Use words, phrases, and/or sentences.)

d. Just keep writing down whatever comes to your mind until you run out of ideas.

In the following example, many ideas have been put down about the topic, Rita, in no particular order, without worrying about grammar, punctuation, or the controlling idea. 
Topic sentence: Rita, my roommate, is very inconsiderate.

- Kitchen in a mess

- She wears heavy make up

- Loves soap operas

- Uses the bathroom for an hour a day every morning

- It is always in a mess

- Fast food freak

- Eats my food

- Conceited

- My phone messages (seldom takes)

- Drives me to work (sometimes)

Then goes back over the list and crosses out any ideas that do not prove or support the topic sentence. As the students go over each point on their list, ask themselves this question: will this point support the controlling idea?

In the example topic sentence, the controlling idea is that Rita is inconsiderate. Let's evaluate the points on the brainstorming list.

a) Rita leaves the kitchen in a mess

- Will this point prove that Rita is inconsiderate?

- Since the answer is yes, leave it in.

b) She wears heavy make up

- This will not support the controlling idea, so cross it out.

Remember that writer must test each point to see whether or not it will prove the controlling idea that Rita is inconsiderate.

\section{b. Step 2: List your supporting points}

The next step in prewriting is to list the points that they will use in the paragraph. Remember, all of them must support the controlling idea of the topic sentence. In our example, the controlling idea is that Rita is inconsiderate the writer can use the supporting points:

a. Leaves the kitchen in a mess

b. Uses the bathroom for over an hour every morning

c. Leaves it in a mess

d. Eats my food

e. Seldom takes my phone messages

The supporting points should be listed in the order in which the students will write about something events. Keep the same ideas together. The example points 1 and 4 should go together. (Kitchen and food), points 2 and 3 should go together (bathroom), and point 5 (telephone) should come last.

\section{c. Step 3: Make a Simple Outline}

The outline is a helpful guide for the students to use in their paragraph. In an outline, they list the man points in the order in which they will write about something event. This will help them to organize thoughts. To help them to stay with the topic, look at their outline as they write in their paragraph. The following is a simple outline form:

I. Topic Sentence

II. Supporting sentences

a. Main supporting sentence 1

b. Main supporting sentence 2

c. Main supporting sentence 3 


\section{Concluding Sentence}

this:

Based on this simple model, the example paragraph about Rita could be outlined like

I. Rita, My roommate, is very inconsiderate

II. a. She leaves kitchen in a mess

b. She eats my food

c. She uses the bathroom for over an hour every morning

d. She always leaves it in a mess

e. She seldom takes my phone massages.

III. In conclusion, Rita is a very thoughtless person

After the students have done the prewriting activities, they are ready to write a good paragraph. Begin the paragraph with the topic sentence. Develop its main point and its supporting details in the paragraph in the order in which they are written in the outline.

Here is the example paragraph about Rita, finally written in paragraph form. The topic sentence is in bold type. The main supporting sentences are underlined. The concluding sentence is in bold type.

Rita, my roommate is very inconsiderate. She leaves the kitchen in a mess. Yesterday, Rita made a sandwich and left the lettuce and mayonnaise on the breadboard. Also, she frequently leaves one or two dirty pots or pants in the sink. Sometimes she eats my food without asking. Last week, she ate the red apple that I was going to take for lunch. This morning, she used up my milk on her breakfast cereal. Besides, Rita uses the bathroom for an hour or more every morning. She showers and washes and blow-dries her hair. She even makes up her face in there. Of course, the bathroom is always in a mess. I have found towels on the floor and toothpaste on the washbasin. She even leaves her dirty laundry on the towel racks. Finally, she seldom takes my phone messages. Last night, I asked her if anyone had called while I was out. But she could not remember Jim or Joe had called. When she does take a message, she sometimes forgets to write down an important phone number. In conclusion, Rita is a thoughtless person. If she does not change some of her ways soon, I am going to look for another roommate.

\section{Research Methods}

\subsection{Location}

The location of the research was SMP Swasta BUDISATRYA. It is at Jalan Letda Sujono Number 166 Medan. The reasons for choosing this school was that the same research have never been conducted in this school.

\subsection{Population and Sample}

The population of this research was the ninth grade students of SMP Swasta Budisatrya. There were four parallel classes. The total was 133 students.

Table 1. Population

\begin{tabular}{|c|c|c|}
\hline No & Class & Total number \\
\hline 1 & IX $^{\mathrm{A}}$ & 34 \\
2 & $\mathrm{IX}^{\mathrm{B}}$ & 34 \\
3 & $\mathrm{IX}^{\mathrm{C}}$ & 34 \\
4 & $\mathrm{IX}^{\mathrm{D}}$ & 31 \\
\hline & Total & 133 \\
\hline
\end{tabular}


To get the sample in this research, the researcher took one class, it was IX ${ }^{\mathrm{A}}$ class. It was caused by efficiency and practicality of the research.

\subsection{Research Design}

This research was based on Classroom Action Research. According to Ferrance (2000), action research is a process in which participants examine their own educational practice systematically and carefully, using the techniques of research which is used for various purposes: school based curriculum development, professional development, systems planning, school restructuring, and as an evaluative tool.

\subsection{The Techniques for Collecting Data}

The procedure of data collection of the study was conducted by administrating for two cycles and three meetings of each cycle. These included four steps namely: planning, action, observation, and reflection.
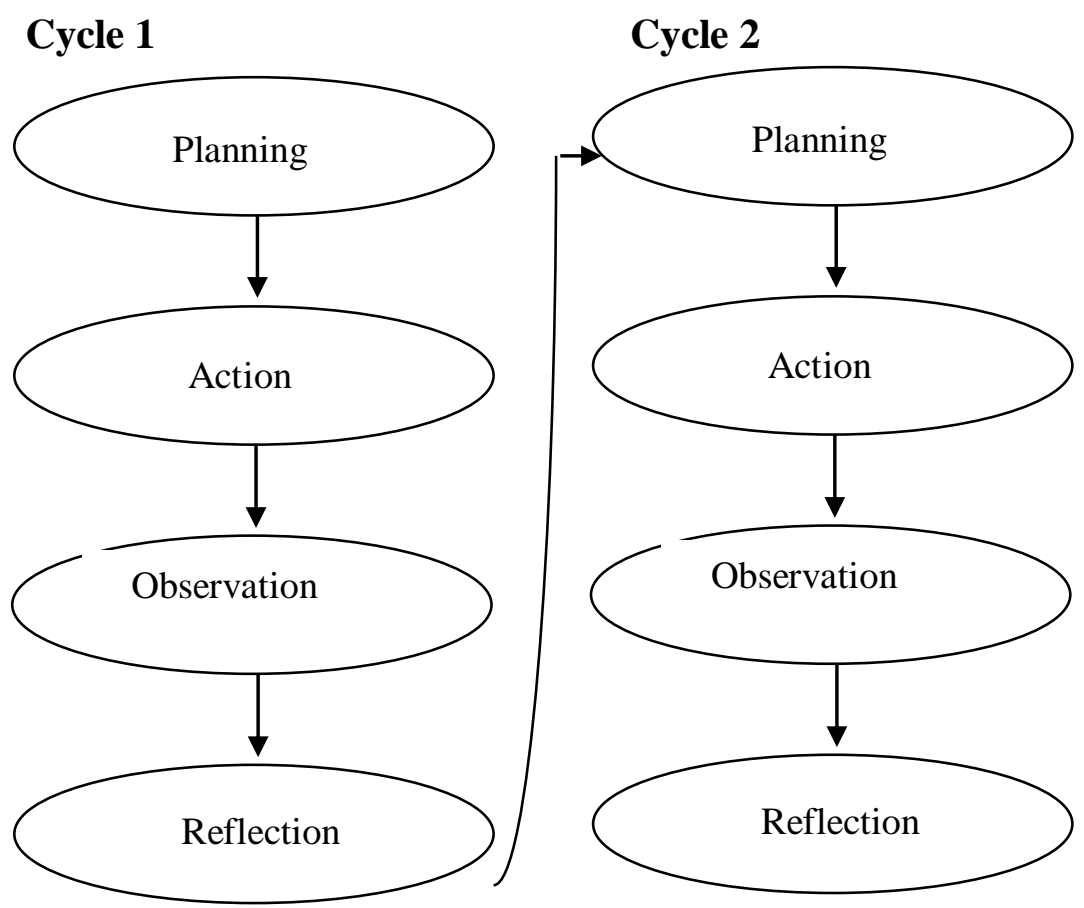

Figure 1. (Riel, M. (2007). Understanding action research: Pepperdine University, Center for Collaborative Action Research.

This research applied quantitative and qualitative data. Quantitative data were taken from the students' writing descriptive paragraph test. Score were used to analyze the improvement of the students' achievement in writing descriptive paragraph for each cycle. The teacher tested the students by some aspects as explained before about testing of writing. Qualitative data were taken from questionnaires sheet.

To find out the class mean score in each cycle, the formula is applied as follows.

$$
\bar{x}=\frac{\sum x}{N}
$$


Where:

$\bar{x}=$ Class mean score

$\Sigma x=$ Total score

$\mathrm{N}=$ The total number of student

To categorize the number of master student, the formula is applied as follows:

$$
P=\frac{R}{T} x 100 \%
$$

Where: $\mathrm{P}=$ Percentage of student getting score 75

$\mathrm{R}=$ Number of student getting score 75

$\mathrm{T}=$ The total number of student taking the test

\section{Discussion}

\subsection{Data Collection}

This study applied Quantitative and Qualitative data. The Quantitative data were taken from the mean of the students in taking listening comprehension test. The Qualitative data were taken from Questionnaire sheet this research was conducted in one class exactly 30 students. It was accomplished in two cycles. Every cycle consisted of four stage of action research. They are planning, acting, observing and reflecting. The first cycle including Pretest was conducted in four meetings. The second cycle was conducting in three meeting altogether. The students were given writing tests at the end of each cycle.

\section{a. The Quantitative Data}

The Quantitative data were taken from the result of writing tests which was carried out into cycles. The improvement of students' achievement in writing descriptive paragraph through teaching prewriting stages can be seen from the mean of the students from the Pretest, Cycle I and Cycle II as follows.

Table 2. The Score Result of the First Meeting until the Seventh Meeting

\begin{tabular}{|l|l|l|l|l|l|l|l|l|}
\hline NO & Students' Initial & Pre Test & \multicolumn{3}{|c|}{ Cycle 1 } & \multicolumn{2}{l|}{ Cycle 2 } \\
\cline { 4 - 9 } & & & $\mathbf{1}$ & $\mathbf{2}$ & $\mathbf{3}$ & $\mathbf{1}$ & $\mathbf{2}$ & $\mathbf{3}$ \\
\hline 1 & FR & 30 & 30 & 40 & 50 & 60 & 70 & 80 \\
\hline 2 & HY & 40 & 40 & 40 & 50 & 60 & 80 & 90 \\
\hline 3 & OL & 40 & 50 & 50 & 75 & 80 & 90 & 100 \\
\hline 4 & MN & 20 & 20 & 30 & 40 & 60 & 80 & 90 \\
\hline 5 & KI & 30 & 40 & 40 & 75 & 80 & 90 & 100 \\
\hline 6 & LI & 30 & 30 & 30 & 40 & 50 & 70 & 80 \\
\hline 7 & GH & 40 & 40 & 50 & 60 & 70 & 80 & 90 \\
\hline 8 & UI & 50 & 60 & 60 & 75 & 80 & 90 & 100 \\
\hline 9 & HI & 30 & 40 & 50 & 75 & 80 & 90 & 100 \\
\hline 10 & KI & 20 & 20 & 30 & 40 & 50 & 70 & 80 \\
\hline 11 & OU & 30 & 40 & 40 & 50 & 60 & 80 & 90 \\
\hline 12 & RF & 30 & 30 & 40 & 50 & 60 & 80 & 90 \\
\hline 13 & ER & 40 & 50 & 50 & 60 & 80 & 90 & 100 \\
\hline
\end{tabular}




\begin{tabular}{|l|l|l|l|l|l|l|l|l|}
\hline 14 & WE & 40 & 40 & 40 & 50 & 60 & 80 & 90 \\
\hline 15 & TI & 40 & 40 & 50 & 60 & 70 & 80 & 90 \\
\hline 16 & UH & 20 & 20 & 30 & 40 & 60 & 80 & 90 \\
\hline 17 & KP & 30 & 30 & 30 & 40 & 50 & 70 & 80 \\
\hline 18 & TR & 40 & 50 & 50 & 60 & 70 & 80 & 90 \\
\hline 19 & FI & 30 & 30 & 30 & 40 & 50 & 70 & 90 \\
\hline 20 & SA & 40 & 40 & 40 & 50 & 60 & 80 & 90 \\
\hline 21 & PI & 50 & 60 & 60 & 75 & 80 & 90 & 100 \\
\hline 22 & EW & 40 & 40 & 50 & 75 & 80 & 80 & 90 \\
\hline 23 & TU & 30 & 30 & 40 & 50 & 70 & 80 & 90 \\
\hline 24 & RE & 40 & 40 & 40 & 50 & 60 & 80 & 90 \\
\hline 25 & SA & 20 & 30 & 40 & 50 & 60 & 80 & 100 \\
\hline 26 & US & 40 & 40 & 40 & 75 & 80 & 80 & 90 \\
\hline 27 & IR & 40 & 40 & 40 & 50 & 60 & 80 & 100 \\
\hline 28 & AR & 20 & 20 & 30 & 40 & 50 & 70 & 90 \\
\hline 29 & YI & 40 & 40 & 50 & 75 & 80 & 80 & 90 \\
\hline 30 & PL & 30 & 30 & 40 & 50 & 60 & 80 & 90 \\
\hline Total Number $(\Sigma x)$ & $\mathbf{1 0 2 0}$ & $\mathbf{1 1 1 0}$ & $\mathbf{1 2 5 0}$ & $\mathbf{1 5 5 0}$ & $\mathbf{1 9 1 0}$ & $\mathbf{2 4 0 0}$ & $\mathbf{2 7 4 0}$ \\
\hline Means $(\bar{x})$ & $\mathbf{3 4}$ & $\mathbf{3 7}$ & $\mathbf{4 1 . 6 6}$ & $\mathbf{5 1 . 6 6}$ & $\mathbf{6 3 . 6 6}$ & $\mathbf{8 0}$ & $\mathbf{9 1 . 3 3}$ \\
\hline
\end{tabular}

Table 3. The students Score for the First until Last Meeting

\begin{tabular}{|l|l|l|}
\hline Test & Students' score got 75 points & Percentage \\
\hline Pre-test & 0 & $0 \%$ \\
\hline First Cycle & 8 & $26,6 \%$ \\
\hline Second Cycle & 30 & $100 \%$ \\
\hline
\end{tabular}

\section{b. The Qualitative Data}

The Qualitative data were taken from the result of Questioner sheet.

\section{Questioner sheet}

From the Questioner which was done in the last meeting. It was found that most of the students were difficult in writing descriptive paragraph before they knew prewriting stages and after the teacher using prewriting stages in writing descriptive paragraph the students were very easy in writing (see Appendix 5). This following is the score of the questioner sheet:

The score of the Questioner sheet
(A) Very easy
(B) Easy
(C) Difficult

Table 4. The score of the Questioner sheet

\begin{tabular}{|l|l|l|l|l|l|l|}
\hline NO & Questions & A & B & C & Number & Word \\
\hline 1. & $\begin{array}{l}\text { Before you were taught by using } \\
\text { prewriting stages, what do you } \\
\text { think about writing? }\end{array}$ & 0 & 5 & 25 & 30 & Difficult \\
\hline 2. & $\begin{array}{l}\text { Before you know about } \\
\text { prewriting stages, how do you } \\
\text { make descriptive paragraph? }\end{array}$ & 0 & 7 & 23 & 30 & Difficult \\
\hline
\end{tabular}




\begin{tabular}{|l|l|l|l|l|l|l|}
\hline 3. & $\begin{array}{l}\text { After you know the prewriting } \\
\text { stages, what do you think about } \\
\text { writing? }\end{array}$ & 14 & 0 & 30 & Very Easy \\
\hline 4. & $\begin{array}{l}\text { After you know the prewriting } \\
\text { stages, how do you make } \\
\text { descriptive paragraph? }\end{array}$ & 20 & 10 & 0 & 30 & Very easy \\
\hline 5. & $\begin{array}{l}\text { What do you think of prewriting } \\
\text { stages in writing descriptive } \\
\text { paragraph? }\end{array}$ & 37 & 0 & 30 & Very easy \\
\hline
\end{tabular}

\subsection{Data Analysis}

a. The Analysis of the Quantitative Data

Seven meetings were conducted in this research and one of them was for the Pre-test. The researcher gave writing tests in each meeting. It was decided to take the result of test in the third meeting as the sample of the students writing tests in the first cycle and the second cycle was taken from the seventh meeting. From the beginning of first cycle until the end of second cycle of this research, students' writing scored improved.

Table 5. Student Score during Conducting the Research

\begin{tabular}{|l|l|l|l|l|l|}
\hline NO & $\begin{array}{l}\text { Students' } \\
\text { Initial }\end{array}$ & $\begin{array}{l}\text { Pre } \\
\text { Test }\end{array}$ & Cycle I & Cycle II & $\begin{array}{l}\text { The Improvement } \\
\text { of Students' score }\end{array}$ \\
\hline 1 & FR & 30 & 50 & 80 & 30 \\
\hline 2 & HY & 40 & 50 & 90 & 40 \\
\hline 3 & OL & 40 & 75 & 100 & 25 \\
\hline 4 & MN & 20 & 40 & 90 & 50 \\
\hline 5 & KI & 30 & 75 & 100 & 25 \\
\hline 6 & LI & 30 & 40 & 80 & 40 \\
\hline 7 & GH & 40 & 60 & 90 & 30 \\
\hline 8 & UI & 50 & 75 & 100 & 25 \\
\hline 9 & HI & 30 & 75 & 100 & 25 \\
\hline 10 & KI & 20 & 40 & 80 & 40 \\
\hline 11 & OU & 30 & 50 & 90 & 40 \\
\hline 12 & RF & 30 & 50 & 90 & 40 \\
\hline 13 & ER & 40 & 60 & 100 & 40 \\
\hline 14 & WE & 40 & 50 & 90 & 40 \\
\hline 15 & TI & 40 & 60 & 90 & 30 \\
\hline 16 & UH & 20 & 40 & 90 & 50 \\
\hline 17 & KP & 30 & 40 & 80 & 40 \\
\hline 18 & TR & 40 & 60 & 90 & 30 \\
\hline 19 & FI & 30 & 40 & 90 & 50 \\
\hline 20 & SA & 40 & 50 & 90 & 40 \\
\hline 21 & PI & 50 & 75 & 100 & 25 \\
\hline 22 & EW & 40 & 75 & 90 & 15 \\
\hline 23 & TU & 30 & 50 & 90 & 40 \\
\hline 24 & RE & 40 & 50 & 90 & 40 \\
\hline 25 & SA & 20 & 50 & 100 & 50 \\
\hline & & & & \\
\hline
\end{tabular}




\begin{tabular}{|l|l|l|l|l|l|}
\hline 26 & US & 40 & 75 & 90 & 15 \\
\hline 27 & IR & 40 & 50 & 100 & 50 \\
\hline 28 & AR & 20 & 40 & 90 & 50 \\
\hline 29 & YI & 40 & 75 & 90 & 15 \\
\cline { 1 - 4 } 30 & PL & 30 & 50 & 90 & 40 \\
\cline { 1 - 4 } $\begin{array}{l}\text { Total Number } \\
(\Sigma x)\end{array}$ & $\mathbf{1 0 2 0}$ & $\mathbf{1 5 5 0}$ & $\mathbf{2 7 4 0}$ & \\
\cline { 1 - 3 } Means $(\bar{x})$ & $\mathbf{3 4}$ & $\mathbf{5 1 . 6 6}$ & $\mathbf{9 1 . 3 3}$ & \\
\hline
\end{tabular}

1. The highest and the lowest score of the first cycle were 75 and 40 points.

2. The highest and the lowest score of the second cycle were 100 and 80 points.

3. The total score of the first cycle was 1550 and in the second cycle 2740 . So, the total score of the second cycle was higher than the first cycle.

The improvement the students' score in writing descriptive paragraph through prewriting stages could be seen from the mean of the students's score during the research, the researcher applied the following formula.

$$
\bar{x}=\frac{\Sigma x}{N}
$$

Where:

$\bar{x}=$ Class mean score

$\Sigma x=$ Total score

$\mathrm{N}=$ The total number of student

In Pre-test, the total score of the students of the students was 1020 and the number of the students was 30 , so the mean was:

$$
\bar{x}=\frac{1020}{30}=34
$$

In test of the cycle 1 , the total score of the students was 1550 and the number of the students was 30 , so the mean was:

$$
\bar{x}=\frac{1550}{30}=51,66
$$

In test of the cycle 2, the total score of the students was 2740 and the number of the students was 30 , so the mean was:

$$
\bar{x}=\frac{2740}{30}=91,33
$$

The mean of the students' score in the cycle 2 was the highest, so it could be said that the students writing descriptive paragraph through prewriting stages increased from 34 to 91,33. The number of master students was calculated by applying the following formula. 


$$
P=\frac{R}{T} x 100 \%
$$

Where: $\mathrm{P}=$ Percentage of student getting score 75

$\mathrm{R}=$ Number of student getting score 75

$\mathrm{T}=$ The total number of student taking the test

$\mathrm{P} 1=$ the percentage of the students who got point 75 to 100 in Pre-test

$\mathrm{P} 2=$ the percentage of the students who got point 75 to 100 in cycle 1

$\mathrm{P} 3=$ the percentage of the students who got point 75 to 100 in cycle 2

The pervcentage of the improvement of students' writing descriptive paragraph could be seen as follow:

$$
\begin{aligned}
& P 1=\frac{0}{30} \times 100 \%=0 \% \\
& P 2=\frac{8}{30} \times 100 \%=26,6 \% \\
& P 3=\frac{30}{30} \times 100 \%=100 \%
\end{aligned}
$$

The result showed the improvement of the students score from the Pre-test to second cycle. The pre-test got $0 \%$, no one of the students got 75 point. The first cycle was $26,6 \%$ (eight students) who got 75 points it means there was an improvement about 26,6\%.

In the second cycle there was $100 \%$ (thirty students) who got 75 points the improvement was $73,4 \%$. It can be concluded that prewriting stages could improve students' writing descriptive paragraph.

\subsection{Research Finding}

The result of the research indicated that there was an improvement on the students' writing descriptive paragraph by using prewriting stages. After collecting data, the mean of the pre-test was still low (34) and it was done cycle I after doing the action by using prewriting stage in cycle I, the result of the first had increased from the pre-test $(51,66)$. Then, after giving action in cycle II, the result of the second cycle test had increased significantly from cycle I $(91,33)$. It implied that prewriting stages was effective in improving students' writing descriptive paragraph.

The Qualitative data that were taken from questionnaire sheet also showed that the students' interest in writing descriptive paragraph because they could share their knowledge and their opinion each other. 


\section{Conclusion}

After analyzing the data, it can be concluded that

1. There were some improvements of students in writing descriptive paragraphs through teaching prewriting stages. It proved from the students' score improved from cycle 1 until cycle 2 .

2. Prewriting stages can help the students to write descriptive paragraphs through brainstorming. In this section, prewriting activity was focused to write down some ideas or feelings of the students have about the subject. Listing supporting point can help them to list point to support controlling ideas. And making a simple outline to write event, place or object related to the topic. It is aimed to organize thought of the students when they wrote descriptive paragraph. So, the students' achievement in writing descriptive paragraph is significantly improved by applying prewriting stage.

The result of this study showed that teaching prewriting stage could improve the students' writing descriptive paragraph. Therefore the following suggestions are offered.

a. to English teachers, it is better to apply prewriting stage to improve the students' writing descriptive paragraph through brainstorming, listing supporting point, and make a simple outline Practically, these activities is useful to improve students' achievement in writing skill, such as getting the ideas, develop their writing through controlling and supporting ideas, and making a simple outline to stay them on their topic of writing.

b. to the students, it is useful to use prewriting stage before writing descriptive paragraph because it gave the students comfortable, fun, and new experience through learning new material which was designed by using making a simple outline.

\section{References}

Adelstein. L and Pival, J. 1984. Writing for Purposes. San Francisco: Longman. Allen, V and Vallette, C. 1981. Writing Skill. London: Moughton.

Amato, PA, Richard and Snow, MA. 2005. Academic Success for English Language Learners: Strategies for K'12 Mainstream Teachers. New York: Longman

Bailey, Jr.1 984. Writing clearly: A Contemporary Approach. Ohio. Moughton

Bazerman, H. 1985. The Informed Writer: Using Sources in the Disciplines. Boston: Mifflin Company.

Bramner, G and Sedley, D. 1981. Writing for Reader. Ohio: Bell and Howell.

Ellis and Hopkins. 1985. Teaching Writing Paragraph. San Francisco: Brighton.

Ferrance, Eileen. 2000. Action Research. Brown University: Brown.

Farmer, G. 1995. Composition and Grammar: Step in the Writing Process. Illinois: Laidlaw Brother Publisher.

Gere, R. 1985. Writing and Learning. New York: Macmillan Publishing.

Harris, D. 1998. Testing English as a Second Language. New York: Mc. Graw Hill.

Heaton, J. 1988. Writing English Language Test. London: Longman

Kants, L. 2001. Improvement Your Vocabulary. London: Longman.

Mc. Crimmon, J. 1984. Writing with a Purpose. Boston: Houghton Mifflin

Oshima, A and Haque, A. 1988. Writing Academic Skill: Writing and Sentences Structure Work Book for International Students. USA: Addition-Wesley.

Riel, M. 2007. Understanding Action Research. New York: Pepperdine University.

Saragih, J.Y., Adisaputera, A., and Saragi, D. (2019). The Effect of Reasoning Skills on Writing of Explanation Text Assessed from the Social Economic Status of Parents in 
Class VIII, SMP Negeri 2 Raya, Simalungun District, Indonesia. Budapest International Research and Critics in Linguistics and Education (BirLE) Journal, 2(3): 78-87.

Sipayung, R.W. (2018). Improving Students' Achievement in Reading Descriptive Text through Reciprocal Teaching Strategy. Budapest International Research and Critics in Linguistics and Education (BirLE) Journal, 1 (1): 29-48.

Stott, R and Avery, Simon. 2001. Writing with Style. Essex: Longman

Sullivan, K. 1984. Paragraph Practice. London: Macmillan.

Trimble in Saraka. 1988. From Paragraph to Essay. London: Longman.

White, C. 1986. Writer's Art: A practical Rhetoric and handbook. California Warsworth Publishing.

http://en.wikipedia. Org/wild/writing 